\title{
Photographic Memories: Nostalgia and Irish Diaspora Writing
}

Aidan Arrowsmith (Staffordshire University, UK)

\section{Abstract}

This essay focuses upon recent Irish migrant writing and the use there of photography to explore issues of memory, identity and nostalgia.

The 'fantasy Irelands' emanating from the diaspora during the $20^{\text {th }}$ century are contextualised in terms of Ireland's changing self-image during this period - from the Literary Revival and Free State, to the Republic and the global Ireland of the 'Celtic Tiger'.

Through analysis of literary and photographic texts from both Irish-Britain and IrishAmerica (including work by Brian Moore, Timothy O'Grady and Steve Pyke), the essay examines the status of the past in recent constructions of Ireland and Irish identity. Significant shifts are detected, particularly in recent work that engages with the undersides of both nationalist and post-nationalist fantasies of Irishness.

\section{Keywords}

Nationalism, Fantasy, Authenticity, Referentiality, Postmodernism, Postnationalism. 


\section{Photographic Memories: Nostalgia and Irish Diaspora Writing}

Aidan Arrowsmith (Staffordshire University)

1.

On St. Patrick's Day, 1994, British brewers Bass launched 'Caffrey's Irish Ale.' In a bid for authenticity, it was presented as originating in 'County Antrim' rather than the more prosaic 'Belfast', and was said to be based on a genuine, old Irish real ale. The search for authenticity was also central to its advertising campaign, which offered a classic image of Irish emigrant nostalgia. In one television advertisement, entitled 'American Bar, Irish Memories', a group of Irish emigrant lads enjoy themselves in a New York poolroom. Orders are shouted for pints of Caffreys. The throbbing, urban music is 'Jump Around,' a track by the band House of Pain. And, with the camera focussing on the wistful yet square-jawed features of one particular emigrant, the appropriateness of that band's name becomes clear. As he gazes off into the far distance, this exile's pain is all too apparent. One sip of his Caffreys does the trick, though. Its authenticity is such that he is immediately transported back in time, back 'home'. The soundtrack fills with the soaring, elegiac strings of Carter Burwell's 'Theme from Miller's Crossing (a reworking of the traditional emigrant air, 'Lament for Limerick') and he is back amidst red-haired colleens and misty green fields, in a small town Ireland that appears to be populated exclusively by the odd drinker, hurler and wild horse. They say nostalgia is not what it used to be. But the Irish diaspora appears captive to this painful longing for belonging amongst one's own. My focus in this essay is on nostalgia as it appears in recent Irish migrant writing, 
and particularly on the recurrent appearance there of photography as a metaphorical portal into the past.

Exile, in John Dahlberg-Acton's words, is 'the nursery of nationality. ${ }^{1}$ In Ireland's case, a seemingly ubiquitous nostalgia is often generalised and equated with Republican nationalism. ${ }^{2}$ This, of course, is no necessary connection. But there is certainly a link between Irish diasporic nostalgia and Irish nationalism, particularly prior to the country's independence in 1922. Most notably, the 'fantasy Irelands' emanating from the diaspora were fundamental in Revivalist 'inventions' of Irishness during the late-nineteenth and early-twentieth centuries. Ironically, and not insignificantly, London, the imperial capital, became the 'crucible' in which influential, late-nineteenth century exiles such as W.B. Yeats, Michael Collins and W.P. Ryan distilled 'the elements to make a modern Ireland'. ${ }^{3}$ In December 1891, a meeting at Yeats's family home founded London's Irish Literary Society, 'an important revivalist enterprise,' according to Clare Hutton. ${ }^{4}$ And that same year saw publication of Yeats's early, autobiographical novella John Sherman (1891), which is exemplary in its Revivalist idealisation of the rural West from an emigrant perspective. The fantasy Ireland of this text is motivated, at least in part, by the increasing marginalisation, in the late-nineteenth century, of Yeats and the Anglo-Irish Protestant Ascendancy amidst Catholic nationalism's growing hegemony. But its personification of alienation and desire for connection takes the form, significantly, of a migrant. As part of his assertion of a national identity that embraced the Anglo-Irish, Yeats's fantasy of Ireland's future as a return to a pre-colonial, Celtic Eden is driven by 
Anglo-Irish migration to London. A central impetus for revivalist nationalism comes from the diaspora.

The enduring ideological function of this nostalgic-utopian ideal is shown by the belatedness of its most famous articulation. This came more than two decades after independence, on St. Patrick's Day 1943. The speaker was that eminent Irish-American, Eamon de Valera, and the occasion was the Gaelic League's fiftieth anniversary. ${ }^{5}$ By the 1940s, as Terence Brown points out, idealistic fantasies 'could only be maintained by ignoring the dismal facts of emigration, economic stagnation, individual inhibition and lack of fulfilling opportunity. ${ }^{6}$ Ireland's revolution, like a wheel, had seemingly come full circle after independence, and the Irish Free State seemed to recast all the old hierarchies. ${ }^{7}$ De Valera's much-quoted speech did not so much ignore reality, however, as seek to compensate it with recourse to a familiar fantasy. His proposal was that the Irish people 'turn aside for a moment' from 'misery and desolation.' As an alternative, they were invited to take refuge in his dream of a Gaelic utopia of the future. This, he promised, would be a non-materialistic, rural paradise, 'whose countryside would be bright with cosy homesteads, whose fields and villages would be joyous with the sounds of industry, the romping of sturdy children, the contests of athletic youths, the laughter of comely maidens; whose firesides would be the forums of the wisdom of old age. ${ }^{\prime 8}$ The confusion, in these nationalist fantasy Irelands, of a utopian future with an idealised, unmodernised past begins to look like a habitual mode of distracting from significant absences in the present. 
Only a few years after de Valera's famous vision, however, the climate for nostalgic-utopian thinking began to change radically along with Ireland's aspirations. In 1948, the great fantasist himself was voted out of government. The Fianna Gael administration of new Taoiseach John Costello passed the Republic of Ireland Act of 19489, by which the disputed twenty-six county State was ratified. The nationalist fantasy object of a unified, thirty-two county Ireland seemed to be receding into the distance. In Chris Morash's words, Ireland in the 1940s and 50s became a 'post-Utopian' culture of hopelessness: 'a culture which no longer trusts the utopian, which in some respects believes itself to have passed beyond utopia. ${ }^{9}$ By 1958 , the old ideals seemed finally to be buried as T.K. Whitaker filed his Report on Economic Development. Recommending that the rural dream finally be ditched and 'modernity' embraced, the Whitaker report paved the way for what Joe Cleary calls the 'single major project'10 of the Irish state after $1958-$ integration into the European Union and global capitalism. As one fantasy Ireland faded, a new one took its place: the fantasy of a postnationalist (post)modernity. ${ }^{11}$

For Fredric Jameson, the social order of late, multinational capitalism is characterised by:

new forms of business organization (multinationals, transnationals) ... the new international division of labor, a vertiginous new dynamic in international banking and the stock exchanges (including the enormous Second and Third World debt), new forms of media interrelationship ..., computers and automation, the flight of production to advanced Third World areas. ${ }^{12}$ 
On the surface, Ireland's integration into the global economy between Whitaker and the Millenium resulted in a 'breathtaking' transformation. ${ }^{13}$ During the 1950 s, three-quarters of Irish exports were agricultural; fifty years later, Ireland was second only to the United States as an exporter of computer software. ${ }^{14}$ In the 1960 s alone, more than three hundred and fifty manufacturing enterprises were attracted to Ireland by the favourable conditions offered by the government. ${ }^{15}$ Barely bothering to stop at modernity along the way, then, Ireland shot from being a largely rural, traditional society into the 'postmodernity' of the international Celtic Tiger. Yet contemporary Ireland's position within the new order of postmodernity is ambiguous at best. Luke Gibbons, for example, has described Ireland as 'a First World country, but with a Third World memory. ${ }^{16}$ For development theorist Peadar Kirby, Ireland might best be seen as a developing rather than a developed country, one of the 'advanced Third World areas' mentioned by Jameson. ${ }^{17}$ The extent to which the contemporary Irish state is built on foreign capital is one factor here. The consequences of this, Kirby argues, are the prioritisation of economic over social objectives and, as a result, an inevitable growth in poverty and inequality:

Relative poverty ... [has] risen consistently between 1987 and 1997 . The distance they fall below the poverty line, while being reduced between 1987 and 1994, increased quite sharply between 1994 and 1997. On inequality in income distribution ... the period 1994-98 shows a redistribution of over 1 per cent of total income away from the bottom 30 per cent. ${ }^{18}$ 
Furthermore, according to Michael Cronin, over thirty per cent of Celtic Tiger Ireland's population lives with the risk of poverty, between nine and fifteen per cent experiencing poverty persistently. Particularly in rural Ireland, nationalist fantasies of an undeveloped, pre-modernity have helped to freeze economic development, with the result that even now, sixty per cent of Ireland's poor live in rural rather than urban areas. ${ }^{19}$ Postmodern idealisations of the rural can too closely resemble idealisations of poverty.

In Jameson's analysis, postmodernity is also a state of backward-looking nostalgia. A confused temporality, as we have seen, is nothing new in Ireland. This is a country often noted during the twentieth century for its backwardness, yet had, a century earlier, produced a radically experimental modernist literature and cultural politics. ${ }^{20}$ Similarly, whilst sometimes being seen to have been modernist before it reached modernity, Ireland has actually long been familiar with the disintegration and fragmentation which so defines the modern - most notably as a result of centuries of colonisation and mass emigration. ${ }^{21}$ 'Everywhere,' according to Kiberd, Irish culture displays a 'strange mixture of backwardness and forwardness'. ${ }^{22}$ Yet, if such ambivalence and temporal confusion has long contributed to the nostalgia of Irish diasporic nationalism, this process is exacerbated in a contemporary world described recently by Zygmunt Bauman as 'liquid modernity.' This, for Bauman, is a world in which identities dissolve to be replaced by a shuttling between twin desires: on one hand is the attractive freedom of postmodern rootlessness, on the other is a reinvigorated desire for rootedness and connection. Older trends of Irish emigration have, particularly since the late 1980 s, become an exponential 'nomadism. ${ }^{23}$ Globalisation revamps the diasporic confusion of home and abroad, past and future, and 
in this context, as Jean Baudrillard suggests, the search for authenticity and connectedness is re-energised to offset the opening lack:

When the real is no longer what it used to be, nostalgia assumes its full meaning. There is a proliferation of myths of origin and signs of reality; of second-hand truth, objectivity and authenticity. There is ... a resurrection of the figurative where the object and substance have disappeared. And there is a panic-stricken production of the real and the referential, above and parallel to the panic of material production. ${ }^{24}$

For Jameson, postmodern nostalgia is most notably articulated in pastiche, such as that of the Caffreys ad. The past, he writes, has 'become a vast collection of images, a multitudinous photographic simulacrum ... [W]e are condemned to seek History by way of our own pop images and simulacra of that history, which itself remains forever out of reach. ${ }^{25}$ Intriguingly, the nostalgic 'dream' sequence in the Caffreys film was labelled 'New Ireland' by the advertisers WCRS. And, indeed, the brand's launch year of 1994 was also that in which U.S. investment bankers Morgan Stanley coined and conferred upon Ireland the name 'Celtic Tiger,' thereby authorising the country's 'reinvention' as a member of the postmodern, global economy. The old nostalgic fantasies of nationalism are not discarded but are re-cast for postnationalist postmodernity. And where de Valera's dream aimed to assuage the 'misery and desolation' of mid-twentieth-century Ireland, the pastiche nostalgia of postmodernity can be seen to articulate similar social, cultural and economic needs, generated out of a very different moment. 


\section{2.}

The cover of Seamus Deane's novel of history and memory, Reading in the Dark (1996), shows a black-and-white photograph of himself and a friend as children. ${ }^{26}$ This faded and dogeared image is distorted and partially hidden, however. Cracked glass from a broken frame appears on the photograph's surface, obscuring the figures and making that artefact historical. As John Tagg puts it, 'Photographs are never "evidence" of history; they are themselves the historical. ${ }^{27}$ The past to which Deane's photograph refers is inaccessible; it is, as Jeff Cottenden's cover design suggests, a construction, visible only through the lens of the present. The very materiality of the photograph attests to its pastness. But the novel itself also deals with the compulsion to seek connectedness and to exorcise the past by weaving narratives. In Deane's critical writing, too, such themes are central. During the 1980s, most of his work advocated a strong anti-essentialism, castigating the Irish 'fetish of exile, alienation and dislocation. ${ }^{28}$ By the time of Morgan Stanley's 'naming' of Ireland in 1994, however, Deane was beginning to defend 'the need that people have to construct an historical identity [and] the viability of essentialist arguments as political strategies. ${ }^{29}$ The lack opened by the ruptures of modernisation and postmodernity is filled, as Baudrillard pointed out, not only by the 'panic of material production,' but also with the 'panic-stricken production of the real and the referential.' For Susan Sontag, photography is therefore a form particularly suited to the global postmodern. 'It is a nostalgic time right now,' she writes, 'and photographs actively promote nostalgia. ${ }^{30}$ 
Just as T.K. Whitaker's radical proposals were being digested and implemented by new modernising Taioseach Sean Lemass, many Irish homes of the late 1950s and 1960s were taking delivery of the first of John Hinde's photographic postcards. Their depicted scenes of 'Ould Oireland' - a donkey bearing the baskets of turf for two small children; 'home' as the archetypal thatched cottage to which the children and the donkey seek return - themselves recall The Quiet Man, the 1952 nostalgia piece by Irish-American filmmaker John Ford (or Sean Feeney as he had previously been known). ${ }^{31}$ Indeed, Luke Gibbons blames Ford's film for launching a thousand of these nostalgic postcards: 'there is an uneasy feeling that we are getting a last glimpse of a world that is lost ... The image operates almost as a flashback on another possible world, as if expressing the spectator's aspiration: "Wish I was there. "132 Hinde's images are indicative of that production of the 'referential' - the search for connection with an authentic past, lost (again) as a result of 'modernization'. Seamus Heaney's 1966 poem 'Ancestral Photograph' is comparable. Here, Ireland's new aspiration to postnationalist (post)modernity is equated with the loss of both economic stability and cultural identity - the latter defined, it seems, in accordance with Daniel Corkery's revivalist mantra of 'religion, nationalism and land'. ${ }^{33}$ This widening lack is explored by Heaney through the trope of a missing family photograph:

My father's uncle, from whom he learnt the trade, Long fixed in sepia tints, begins to fade And must come down. Now on the bedroom wall There is a faded patch where he has been- 
As if a bandage had been ripped from skin-

Empty plaque to a house's rise and fall. ${ }^{34}$

Gone are the agrarian trades practised by the speaker's great uncle. They have receded into the past, and with them has gone authentic Irishness. That tradition, and connection with it, had once been made present, it seems, by the photograph. As in Hinde's images, a faith is apparent in the photograph's referentiality. Before modernisation severed the link, it was a portal into an authentic past. This is a view of photography that finds an echo in Roland Barthes's Camera Lucida (1980). Jefferson Hunter points to the influence of Jean-Paul Sartre on this text, particularly his 1954 introduction to Henri CartierBresson's D'une Chine à l'autre, in which Sartre opposed the inadequacy of writing to photography's authenticity. ${ }^{35}$ Barthes's search for the past is focussed upon an old photograph of his mother as a child. It is the indexibility of such images that, for Barthes, constitutes their mysterious allure - the actual, physical link he sees between the viewer and the subject:

The photograph is literally an emanation of the referent. From a real body, which was there, proceed radiations which ultimately touch me, who am here; the duration of the transmission is insignificant; the photograph of the missing being, as Sontag says, will touch me like the delayed rays of a star. A sort of umbilical cord links the body of the photographed thing to my gaze. ${ }^{36}$ 
Heaney's and Barthes' shared interest in the photograph could be seen to exemplify what Linda Haverty Rugg describes as a 'naïve' approach to the question of the referentiality of the image. 'Even poststructuralists,' she argues, 'once they have dismantled textual referentiality, must have something in which to believe; and this is where photography enters the fray. Both Roland Barthes and Paul de Man, who profess disbelief in the referential power of language, seem to become remarkably gullible when it comes to photographs'. ${ }^{37} \mathrm{~A}$ more 'sophisticated' approach to photographic referentiality, like that suggested in Cottenden's cover design for Deane's 1996 novel, can be seen in recent literary work emanating from a range of different contexts. ${ }^{38}$ Paul Auster and Don DeLillo, for example, both use the photograph as a metaphor through which to explore critically the attraction to nostalgia and search for identity in contemporary America. In DeLillo's Underworld (1997), for example, Marvin Lundy searches for a baseball that, for him, is redolent of a lost stability - both his happy childhood and America's Cold War. Frustrated in his search, though, his nostalgia is channelled into a forensic, and fetishistic, study of photographs of baseball games: 'This is what technology does. It peels back shadows and redeems the dazed and rambling past. It makes reality come true'. ${ }^{39}$ While DeLillo's novel includes no images, the Anglo-German writer W.G. Sebald incorporates a variety of photographic images alongside his words in books such as The Emigrants (1993) and Austerlitz (2001). The photographs are sometimes presented as precious artefacts in their own right, bearing, like Deane's photograph, the scars of their own pasts; elsewhere they appear simply as vehicles carrying representions of important people, places or times past. Side by side, text and images evoke in intriguing ways Sebald's key themes of migrancy, identity and loss. They express the ambivalent 
requirement of contemporary Germany, and especially its diaspora, both to remember and not to remember the past. An attempt is made to preserve a remainder of the past that is in many ways unassimilable, what Jean-François Lyotard calls 'the unforgettable forgotten. ${ }^{140}$ At the same time, the books problematise the act of memory. The words and images are both elusive and the sense of these texts as attempts to organise the past is in tension with their adoption, formally, of the disruptive logic of memory. The referent meaning, or the past - is always out of reach, even in photography.

In the contemporary literature of the Irish diaspora, similarly, the photograph recurs as a problematic route to the (re)connection with roots. Both of the two novels upon which I will now concentrate date from the post-Whitaker period. But whilst Brian Moore's The Mangan Inheritance (1979) dates from before the advent of the Celtic Tiger, I Could Read the Sky by Timothy O'Grady and Steve Pyke is from 1997, with the Tiger pacing ahead. Moore's novel shares an approach with DeLillo in that photographs are present only as metaphor; I Could Read the Sky, on the other hand, echoes Sebald and the collaborations between John Berger and Jean Mohr in its inclusion of images alongside the text. As such, it becomes what Jefferson Hunter calls a 'photo-text', defined as 'composite publications evoking a landscape or recording a history, celebrating a community or mourning a loss'. ${ }^{41}$ Both Moore's and O'Grady/Pyke's books share a 'sophisticated' approach to the question of the referentiality of photography. They concur less with Barthes's idea of the connectedness available in photographs than with Deane's suggestion of the impossibility of accessing or escaping the past. Moreover, they echo 
Sontag's sense of absence driving desire: what she calls the 'muteness' of photographs is the generator of fantasy:

A photograph is both a pseudo-science and a token of absence. Like a wood fire in a room, photographs - especially those of people, of distant landscapes and faraway cities, of the vanished past - are incitements to reverie. The sense of the unattainable that can be evoked by photographs feeds directly into the erotic feelings of those for whom desirability is enhanced by distance ... The very muteness of what is, hypothetically, comprehensible in photographs is what constitutes their attraction and provocativeness. ${ }^{42}$

This approach to photography is integral to these texts' self-conscious confrontation of a history of Irish diasporic nostalgia.

3.

In 1948, de Valera's nationalist dreams were doubly shattered, first by his deposition as Taoiseach and then by the Republic of Ireland Act. Also in 1948, as if to illustrate the persistence of emigration in mid-twentieth-century Ireland, yet another Irish writer departed. Brian Moore's initial destination was Canada, from where he later moved to the United States. In The Mangan Inheritance, Moore's novel of 1979, the nostalgic fantasies emanating from the late-twentieth-century diaspora are attacked by way of their equation with those of nineteenth-century revivalist nationalism, echoes of which were still 
sounding loudly even in the late forties. At the outset of the novel, Moore's main protagonist, Jamie Mangan, is suffering a classically diasporic crisis of identity. As in the Caffrey's ad, the fantasy is generated out of New York - de Valera's birthplace and, not insignificantly, the antithesis of his rural ideal. From this setting, Jamie's crisis might also be seen to be postmodern or 'liquid modern': all his categories of belonging have dissolved. He is of Irish ancestry, Canadian birth and U.S. citizenship, and therefore his return to Canada (let alone to Ireland) is, confusingly for everyone, as a foreigner. Nor can he claim 'proper masculinity'. When married to his film star wife, he had felt himself to be merely her husband, wholly supported by her and, in this classic role reversal, negatively defined in relation to her. Now, however, with his marriage ended, Jamie exists merely as a failed poet searching in vain for a voice. 'By Byron's standards,' as the narrator comments ironically, 'he was not a man'.43

Jamie's only hope for the future, his only prospect of resolving his identity crisis, seems to lie in the past. His discovery amongst his father's family papers of an old daguerreotype stimulates a search for connection with that past by revisiting the 'motherland'. Despite being one hundred years old, this picture seems, uncannily, to depict his own face; this is the daguerreotype as described by Oliver Wendell Holmes in 1861 - a 'mirror with a memory. ${ }^{144}$ Jamie's reaction recalls the Barthesian 'punctum' - that element of a photograph which, Barthes writes, 'rises from the scene, shoots out of it like an arrow, and pierces me ... is poignant to me'. ${ }^{45}$ Like Barthes, Jamie believes in this photograph's 'umbilical' link to the past, its potential to transport him and connect him to some elusive origin of identity. As Nicola King has written, photographs can seem 'closest 
to the "original" image which forms the content of [cultural] memory'. ${ }^{46}$ For Jamie, certainly, the photograph connotes that 'unforgettable forgotten' which 'remains' beyond representation, an authentic past beyond the limitations of writing.

As well as being classically diasporic, Jamie's desire-driven fantasy of identification is characteristic of what Celia Lury calls the 'prosthetic culture' of postmodernism. Photographs, she argues, have become so central in the construction of contemporary identities that a move is made from a Lacanian (mis)identification towards what Barthes refers to as 'the advent of myself as other'. ${ }^{47}$ The other who Jamie seeks to become is nineteenth-century, Irish nationalist poet, James Clarence Mangan, whose face - identical to Jamie's - is that depicted in the daguerreotype. This voice of Irish cultural nationalism is his Doppelgänger, as the narrator says, 'He must be that man's blood' (61). The symbolic significance of Mangan lies, at least in part, in his association with a tradition of anti-colonial nationalism whose constructions of Irishness often centred upon an idealisation of femininity. Mangan's most famous ballad, 'Dark Rosaleen', is a classic of this genre. This inspirational fantasy of Irishness in female form appeared in 1846, amidst the desperation of increasing starvation and emigration consequent upon the Great Famine. Despite the motivation to fantasy of such a context, feminist critics and writers such as Eavan Boland rightly contend that this tradition, to which Jamie Mangan now finds himself connected, achieves an authoritative 'Irish national' voice at the expense of women: 
The majority of Irish male poets depended on women as motifs in their poetry ... The women in their poems were often passive, decorative, raised to emblematic status. This was especially true where the woman and the idea of nation were mixed: where the nation became a woman and the woman took on a national posture ... [Women became] elements of style rather than aspects of truth ... the passive projection of a national ideal. ${ }^{48}$

The reduction of women to mere metaphors thus enables an Ireland emasculated by colonisation and famine to regain a masculine, authoritative identity with which to combat the coloniser. Jamie's photograph, therefore, becomes a passport not only to the past but also to his inheritance of the Irish masculinity associated with this cultural nationalist tradition: 'He picked up the daguerreotype, mysterious passport which had enabled him to cross the frontier of [his] fears ... And looking into the eyes of his Doppelgänger, that strange elation came over him again ... He must be that man's blood, heir to a talent of which until now he had been an indifferent caretaker' (61). Feeling himself thus connected, and clutching his 'passport into the past', Jamie sets out on a nostalgia trip - a revivalist 'return to the source' back in authentic 'ould' Ireland. ${ }^{49}$

Let us temporarily leave Jamie suspended above the Atlantic, fantasising about Ireland, and move to London, which is the setting for I Could Read the Sky (1997) - a photo-text comprising fiction by Timothy O'Grady and photographs by Steve Pyke. The novel's protagonist is the archetypal Irish migrant figure, the working-class 'navvy' in London, subjected to prejudice and harking back, in time-honoured fashion, to an idyllic 
time before the break. O'Grady self-consciously locates this novel within a long tradition of classic accounts of just such a migrant experience, including Patrick MacGill's Children of the Dead End (1914), Pádraic Ó Conaire's Deoraíocht (Exile) (1910) and Donall Mac Amhlaigh's Dialann Deoraí (An Irish Navvy) (1964). O'Grady's text plays knowingly with stereotypes of the Irish in Britain - working, drinking and brawling, but also brimming with nostalgia for an idealised home. ${ }^{50}$ By comparison with Moore's novel, this book also takes a different approach to the use of photography as a means of exploring memory and diasporic nostalgia. In this photo-text, Pyke's enigmatic black-and-white images are placed alongside O'Grady's text. For Hunter, 'The words and photographs of photo texts contribute equally to their meaning; that is how the genre is defined. They must simultaneously be read and viewed. ${ }^{51}$ Pyke's images in this book do not illustrate the words, but act as a different medium through which to represent the protagonist's memories. In juxtaposition, and often as a result of the tension or disjuncture between them, the text and images function to reveal the desires and fantasies through which this migrant narrator constructs his memories of 'home'. The book reveals how his memories of the past are reshaped, re-presented according to the requirements of the present.

'Cliffs of Moher, Co Clare (1987)', for example, is a Romantic memory of the natural landscape 'back home'. 


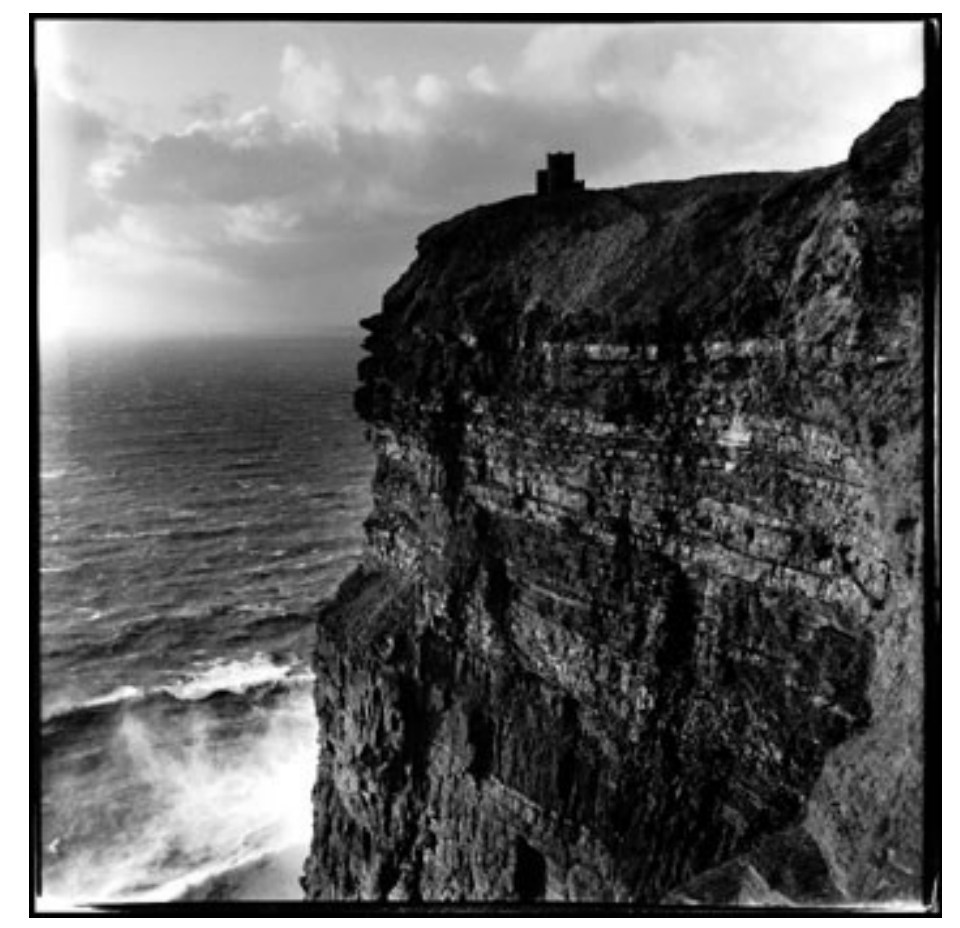

Cliffs of Moher, Co Clare (1987) (c) Steve Pyke 52

The point-of-view in this image positions the narrator at one with this sublime nature. The power and magnitude he thereby possesses stand in profound contrast with the mundanity, poverty and powerlessness offered by his migrant life in a Kentish Town bedsit. It is to this, however, that he grudgingly awakes from his reverie: 'Always this neutral air ... A chair beside the bed. Tablets. A shirt with little blue squares, the collar shot ... Is there a kind of sum to this? I wait'..$^{53}$ Somehow, though, London is not the narrator's 'true reality'. Given a few minutes, he is able, he says, to 'get back' to his memories - to get 'back home' to the authenticity of his fantasies. This deliberate blurring of fantasy and reality is central both to the text's form and its content. As in those classic Irish migrant narratives, this text seems to sit on the borderline between fiction and autobiography (on p.105, for example, a composite photograph of Christian gravestones 
includes the headstone of ' $\mathrm{O}$ 'Grady'). This is a terrain also inhabited by Reading in the Dark, and Deane comments: 'where the real and the phantasmal coincide with one another, that's the mark of a colonized society'. ${ }^{54}$ At every level of O'Grady and Pyke's text of contemporary, 'greater' Ireland, there is an interpenetration of fantasy and reality, past and present, troubling the search for meaning or for an authentic past.

Fantasy is also the major ingredient forming the County Cork seen by Jamie Mangan when he touches down in the 'motherland'. Declan Kiberd has argued that Irish people 'no longer live in a country of their own making, but in a kind of tourist's filmset ... Once a rude imposition, the pastoral Ireland of Yeats and de Valera has now become a downright oppression. ${ }^{55}$ This resort to what Marx called 'the idiocy of rural life' has in large part been driven, Kiberd implies, by the economic power, especially the tourist dollar, of the Irish diaspora. Fantasy and currency emanate together from the diaspora and help to freeze parts of Ireland as a 'theme-park' of authenticity. In Moore's novel, the Irish-American Jamie is shown (re)discovering precisely his fantasy Ireland - the Ireland his desires had helped to construct. Having come in search of roots, he finds exactly the authoritative masculinity and authentic nationality that, like generations of emigrants, he had imagined. The Cork landscape is described in appropriately parodic and fantastical terms, all exaggerated greenery, mystical landscapes and stereotypical Colleens. This is a hypergreen, supernaturally authentic Irishness, and comes straight out of John Hinde or The Quiet Man. ${ }^{56}$ Unsurprisingly, it is all strangely familiar to Jamie: 
Wild-looking, poorly dressed people walked about, raw boys and girls, women in mourning black, red-faced farmers in cloth caps ... [T] he evening sky was filled with an almost supernatural light. The lighthouse flashed suddenly like a signal from a secret source. As he looked down at the fields surrounding the bay, it seemed to him that he had gone back in time: there was a stillness in this scene as in a painting of medieval times. The distant vista of fields, the church spire and the slate rooftops far below, all of it was like a world long gone, ... unchanged and unchanging $(95,105)$.

But Jamie becomes increasingly trapped by the nationalist fantasy that is his 'inheritance'. He finds himself able to recite James Clarence Mangan's words 'as though they were my own poems ... It's strange ... It's uncanny' (57). He is also, in due course, obliged to play out the archaic roles that are embedded within this nationalist assertion of Irishness. In the sexual relationships he develops with the (too) young red-head 'Kathleen' (his 'Red Rosaleen'); in the brawling, drinking persona of the poète maudit which is another nonnegotiable condition of his inheritance; even in the scars and missing teeth collected in his bar-room battles, he becomes James Clarence Mangan. Or at least, he becomes a facsimile of the photographic image that symbolises this particular strand of Irish identity. Jamie's response to the daguerreotype echoes Barthes's faith in photography as a portal into the past. But as Sontag points out, 'precisely by slicing out this moment and freezing it, all photographs testify to time's relentless melt. ${ }^{157}$ Photography is closer to amnesia than to memory, according to Pavel Büchler, representing 'an impossibility of recollection. The past, the very matter of the photographic image, cannot be recovered from beyond 
the horizon of the photographic event - the image is always a fatal accident, an end, a terminus, an exit point, never the point of entry. ${ }^{158}$ Gradually, Jamie's faith in the 'umbilical link' is eroded as he begins to recognise the past as a fantasy woven from the threads of his present desire. Amidst the 'liquid modernity' of New York, he had anticipated the connectedness and security of a nineteenth-century identity. But now, his different standpoint renders such 'nationalism' as entrapment and oppression: 'the elation which had filled him in the past when he had looked at his unknown Doppelgänger changed to fear. It was as though the daguerreotype was now a document sentencing him to some future doom, ... [a] mutilated passport to future decay' $(250,308)$.

Trapped within a self-defeating cycle in which the past is fetishised and repeated, Jamie's fate echoes twentieth-century Ireland's stagnation, its continuing poverty and emigration under hegemonic Catholic nationalism. For Joe Cleary, Moore can be classified as one of the Irish 'naturalists', borne out of disaffection with mid-century Ireland, whose 'aesthetic of diminished expectations ... set out to deprogram the romantic utopian impulses of the literature of the Revival. ${ }^{159}$ As Cleary shows, Revivalists such as Yeats actually shared with these later 'naturalists' a scornful view of the new state, but differed significantly in their attitude towards modernisation: 'while Yeats conceived of th[e] provincial and puritanical new Ireland as only too typical of the bourgeois-industrial modernity he detested, the naturalists were convinced that the ills of post-independence Ireland were to be explained, rather, by its lamentably archaic rural social order, and that their task, therefore, was to release it into modernity. ${ }^{\prime 60}$ For naturalists such as Moore, then, Ireland was just not modern enough. Despite entry into the EEC in 1973, the Irish 
1970s were seen to retain too many residues of the old order. Peadar Kirby, for example, sees this decade as one of continued 'stagnation'61; and whilst Terence Brown acknowledges improvements in some areas of Irish social and cultural life, he argues that these were undercut by elements incompatible with Ireland's burgeoning self-image:

poor housing conditions, in bleak, ill-planned areas of the major cities were settings for vandalism, drug abuse, petty crime and lives of quiet desperation ... Despite the economic improvements of the last two decades, poverty, particularly in the inflation-dogged seventies, has scarred the lives of many Irishmen and women in years when social progress, the outcome of increased opportunities in a modernizing society, was assumed to be a primary contemporary fact. ${ }^{62}$

Discontentment during the 1970s was further pressurised by the 'troubles', which centred in part on Moore's own native Belfast. Published in 1979, The Mangan Inheritance thus shares the sentiment expressed that same year by Deane, who was born in another city of 'troubles', Derry: 'nothing is more monotonous or despairing than the search for the essence that defines a nation. ${ }^{63}$ With little room for nostalgia or utopia, Moore's novel concentrates on the damage done by these urges, specifically the nationalist search for connection with the past.

4. 
I Could Read the Sky concentrates less on the consequences of these fantasies than on the absences and deficiencies that, despite the 'progress' of modernisation, remain in the era of postnationalist postmodernity. Critics of Irish modernisation such as Kirby, Gibbons and Cronin argue that the image of postmodern Ireland as a 'modern vibrant economy and society' that appears in recent cultural and political discourse has been constructed only by obfuscating certain realities, by 'pathologis[ing] as extrinsic' the problematic elements of modernisation which do not fit 'New Ireland's' self-image. Instead of acknowledging poverty, inequality and migrancy as logically integral to postmodernity, they are represented as residues of the 'bad old days' of a reactionary Catholic nationalism - 'aberrations from another era ... of bicycle clips, Brylcreem and the Ballroom of Romance. ${ }^{\prime 64}$ The rural idyll, though, is not rejected in this new Fantasy Ireland. Instead, it often reappears in commodified form. As Gibbons points out, Ireland's participation in the global economy is promoted by the Irish Industrial Development Authority by casting postmodern Ireland as 'paradise' now: 'The Most Profitable Industrial Location in the EEC,' the slogan goes, 'is also ... one of the most beautiful'. ${ }^{65}$ With a 'magical reconciliation' having been made between nature and industry, landscape and technology, the shamrock 'acquires a new biochemical identity. ${ }^{166}$ Caffreys' commodification of romantic Irishness stands as one of many advertising images which, in the words of Kirby et al, 'play endlessly on the allure of desert islands, Nature, or romantic escapism in general, as if the commodity ... has become the final outpost of fantasy and consumer gratification. Romantic Ireland may be dead and gone but that has not prevented it re-emerging in commodity form. ${ }^{67}$ Here, postnational, postmodern Ireland is distanced from a backward past seen to be finished, a manoeuvre that appears in a range of contemporary literary 
texts. Vic Merriman argues forcefully that the internationally successful plays of Martin McDonagh - himself a member of the diaspora as a second-generation Irish-Englishman elide and therefore support the inequalities of postmodern Ireland. McDonagh constructs a laughable 'them', located in the rural past, over-against whom a sophisticated, global, twenty-first-century 'we' are united. ${ }^{68}$ The sanitised, pastiche version of Irishness that emerges is dependent upon 'painting out the bits that don't fit the picture'.69 It is nonetheless central to 'Celtic Tiger Ireland' and, as Kirby et al maintain, helps to promote Irish industry, elitist capital accumulation and, inevitably, to exacerbate social inequality.

O'Grady and Pyke's text, on the other hand, functions to expose many of the absences which lie, unspoken, behind such fantasies. The composite photograph entitled 'Hands (1993)', for example, is full of muteness and absence. 


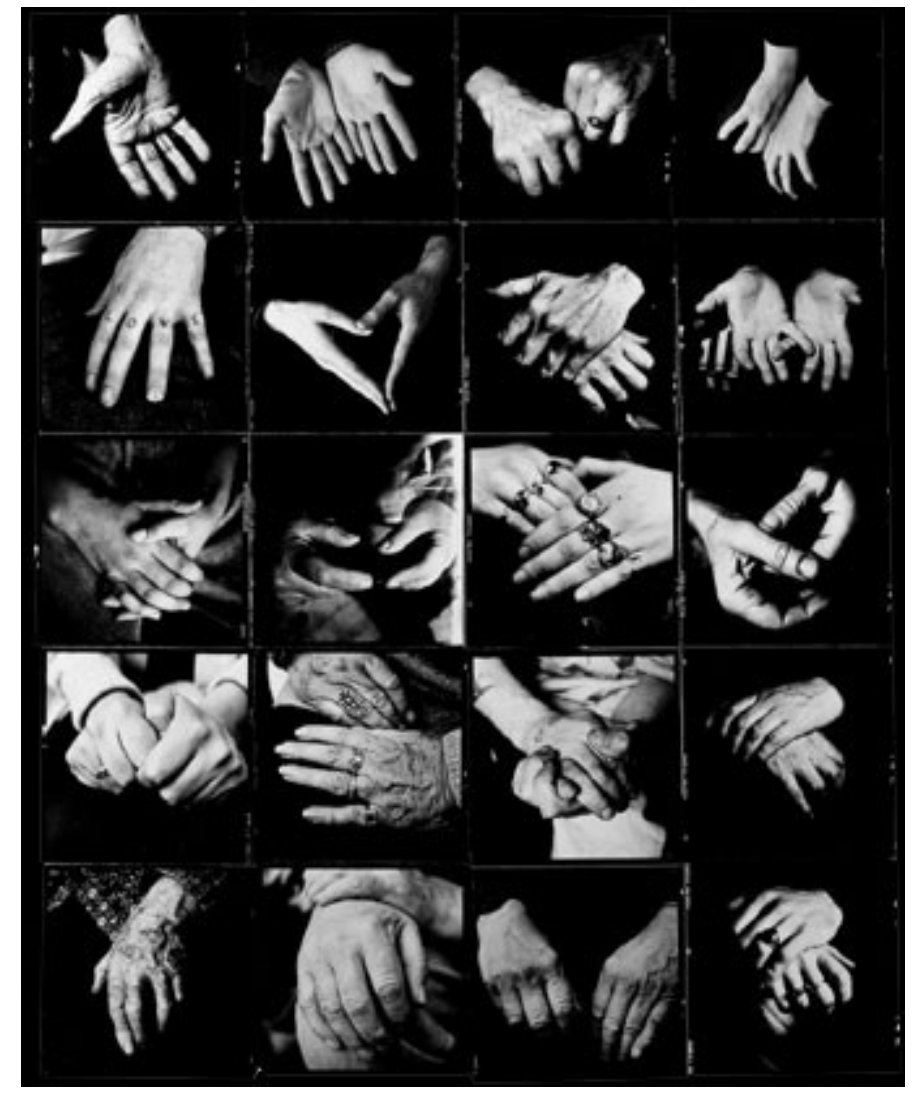

Hands (1993) @ Steve Pyke

This, in common with many of the book's other photographs, is a poignant image of the scars of labour. It denotes an often unspoken story of hardship endured by the Irish poor: including a rural peasantry whose real experience of a harsh life in the West was written out of nationalist idealisations such as Synge's or Robert Flaherty's ${ }^{70}$; an urban proletariat whose existence was rarely even acknowledged in that discourse; and, of course, the working-class Irish who migrated to Britain over a period of more than one hundred and fifty years. By their attitudes of melancholy and by their occasional attempt at expression, these hands convey the voicelessness of their owners. Moreover, as they clutch at and cradle one another, they signify a profound absence of fulfilment and connectedness, a lost link with the 'motherland'. Such hands, especially in connection with maternal 
imagery, in fact recur as a motif throughout the texts of various diasporas. In Franz Kafka's America (1927), for example, the emigrant Karl forensically studies his treasured bundle of family snaps and 'notice[s] his mother's hand, which dropped from the arm of the chair in the foreground, near enough to kiss. ${ }^{11}$ In an Irish context, Colum McCann's Songdogs (1995) is a novel centrally concerned with the interaction of memories, identities and photography. McCann follows his protagonist Conor on a mission which recalls that of Barthes, whose obsessive interest in the photograph of his mother is in part driven by the way 'she was holding one finger in the other hand ... in an awkward gesture. ${ }^{72}$ The twenty-something son of an Irish photographer father and Mexican mother, Conor begins Songdogs as Bauman's typical 'liquid modern' subject, shuttling (backpacking) between its twin poles. On one hand is freedom via the rejection of nationalism's roots fetish. On the other is a growing need for connectedness and identity amidst the fragmentation of the contemporary postmodern. Having moved to London in a bid to escape, he then travels to Mexico in a quest for connection with his late mother. Happening upon an old photograph of a Bronx tenement street in the 1950s, he experiences something akin to Sontag's 'reverie'. He enters the image and, it seems, the past. The scene is full of Irish immigrants, but there at the back, he spots her:

just about smiling as she looks down at her hands ... Maybe she's wondering what she's doing here ... Wondering if life is manufactured by a sense of place, if happiness is dependent on soil, if it is an accident of circumstance that a woman is born in a certain country ... She remains looking at her hands as I ghost my way through the photograph ... I move on down to the end of the cul-de-sac, nod to my 
father as his fingers press on the shutter button, but he doesn't nod back. ${ }^{73}$ (138, 141)

The mother's hands, once the intimate, tactile point of connection to origin, now signify only loss and emptiness for Conor. The connection he seeks eludes him. The past is frozen. Likewise, and contra to Linda Haverty Rugg's suggestion, Barthes' quest for maternal connection ends in a similar acknowledgement: 'History ... separated me ... I cannot penetrate, cannot reach into the Photograph. ${ }^{74}$ As in The Mangan Inheritance, where Jamie realises the hollow myth at the centre of history and identity, Barthes and Conor recognise that the past lives only as a kind of absence, a mysterious remainder, the 'unforgettable forgotten'. The photograph is no simple door to the real.

I Could Read the Sky opens with an image of a padlock, and photographs of locked doors reappear throughout. ${ }^{75}$ Although seeming to confirm a 'sophisticated' approach to the question of textual and photographic referentiality, the absence of connectedness and troubled bid to return 'home' that such images suggest does not affect the novel's nameless protagonist in his compulsive search. In fact his perseverance is compounded, and he adopts a succession of different identities: 'McNamara was a name I used, after the song sung by Americans. O'Neill for the great king of the North. Loss, because of the bandleader. You could be on a site those days and half of them would be calling themselves Michael Collins for the crack' (90-1). Identity is acknowledged as a performance, an image, as it is in the Peter Woods poem with which the novel is prefaced: 
Exile is not a word

It is the ...

Triumph of memory over topography

... It is shaving against

A photograph not a mirror ${ }^{76}$

To recall Baudrillard, the real is clearly no longer what it was, and a panic-stricken search for connection with the referent is inevitable. By the end of the novel, however, when the narrator revisits that same locked door and attempts to open it, he finds the house behind derelict and his family gone: 'I cannot find them. They are passing. There is only the sound of the river drifting through grass, the wind rising ... Again I begin to walk. The names of the places around me begin to weaken and fade ... I walk in forgetfulness, all that I pass seeming to vanish as I go' $(156,159)$. 'Home' and identity are infinitely elusive, receding referents.

In combination with O'Grady's words, however, Steve Pyke's photographs evoke more than just this absence of connectedness. Even as 'Hands' suggests disconnection and the futility of nostalgia, this image articulates the material realities by which that nostalgia is driven. 'Muteness', as Sontag says, is an 'incitement to reverie', and it is absence that is key to the interplay of text and image in this book. In his preface to the novel, John Berger notes the incompleteness of Pyke's photographs, seeing this as the source of their mystery and profundity: 'they remind you of this search for what can't be 
seen, for what's missing; never for one moment do they pretend to be complete. ${ }^{177}$ Such a lack, as well as mirroring the narrator's unattainable 'home', also echoes Barthes's punctum. This, Barthes argues, is generated from the supplement brought to the photograph by the viewer/reader: 'it is an addition: it is what I add to the photograph. ${ }^{178}$ Pyke's images represent cultural memories, and their incompleteness invokes a lack at the heart of contemporary Irish culture, home and abroad. They demand the addition of Lyotard's 'unforgettable forgotten'. In doing so, they conjure those repressed, unspoken, unassimilable elements that are obscured by the fantasy Ireland of postnational postmodernity. Like The Mangan Inheritance, this book exposes essentialist myths of home. But whereas Moore's critique seems to imply a belief in the 'progress' of modernity, such faith is absent from I Could Read the Sky. O'Grady's late-twentieth-century narrator is homeless both symbolically and literally, materially, as the image entitled 'Deserted Houses, Co Kerry (1994)' suggests. 


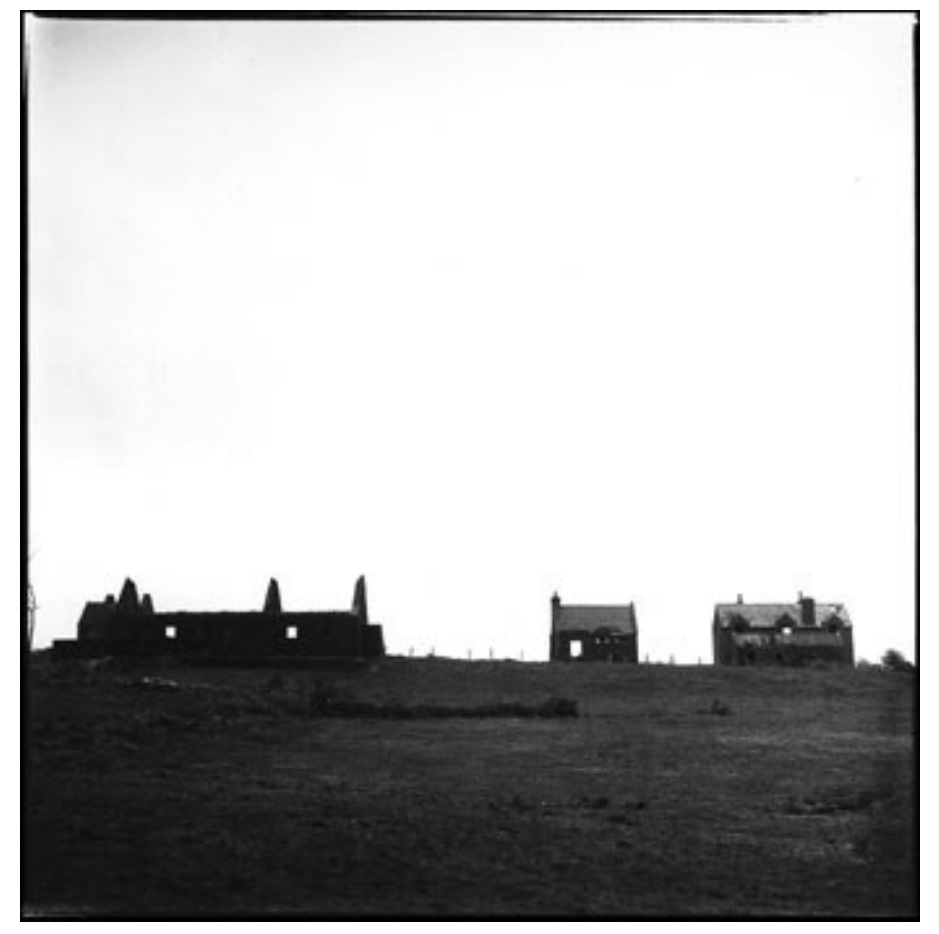

Deserted Houses, Co Kerry (1994) (c) Steve Pyke

This is clearly no mythologisation of the West of Ireland, no arcadian fantasy offsetting the 'misery and desolation' that, unwittingly, it helped to cement. Nor is it a pastiche rendering of a commodified Irishness, an idealisation of modernity. This, instead, is the underside of fantasy Ireland. Here, 'postnationalism' is seen to retain the old deficiencies. Poverty, inequality, homelessness, migrancy: all are highlighted and appear not as 'aberrations' or residues from a different, nationalist era, but as integral to Ireland's present. These obscured elements re-emerge in images such as 'Deserted Houses'. This is a photograph taken in the same year as the Caffreys launch and the baptism of the 'Celtic Tiger', but which at the same time evokes the deserted villages abandoned at the time of the famine - and of James Clarence Mangan's fantasies of 'Dark Rosaleen'. The 'muteness' in Pyke's images summons those elements which are airbrushed out of various 
fantasy Irelands. Unwelcome ghosts of Ireland's past and present are conjured and they parallel different periods of inequality, different kinds of homelessness and 'misery and desolation', across a century and a half. By countering the idealised fantasy of postnationalism and postmodernism, O'Grady and Pyke's emigrant narrative once again recalls John Berger in its communication of a political responsibility to remember:

Photographs are relics of the past, traces of what has happened. If the living take that past upon themselves, if the past becomes an integral part of the process of people making their own history, then all photographs would reacquire a living context, they would continue to exist in time, instead of being arrested moments. It is just possible that photography is the prophecy of a human memory yet to be socially and politically achieved. Such a memory would encompass any image of the past, however tragic, however guilty, within its own continuity. ${ }^{79}$

'Presenting' the past for Berger, as in O'Grady and Pyke's text, is pressurised by the urgency of bringing to light the undersides of the fantasy, of blasting a 'time of the now' out of the 'homogenous, empty time'80 of global capitalism.

5.

In neither The Mangan Inheritance nor I Could Read the Sky does the photograph purport to present the past 'as it really was'. Instead it operates as what Nicola King calls 'an unstable mediator ... between past and present lives and selves. ${ }^{181}$ No authentic past or 
identity exist in these texts. As Jacques Derrida says of the Barthesian punctum, 'its "presence" forever escapes me, having already receded into the past. ${ }^{82}$ In Moore's antiessentialist novel of the 1970s, the nationalist search for authenticity - and especially that emanating from the diaspora - is held responsible for Ireland's stagnation during a backward-looking twentieth century. Modernity, it seems, has not progressed far enough, has not yet destroyed such 'dangerous nostalgia'. Two decades later, though, O'Grady and Pyke's text refers to a radically different context. In its contemporary culture of postnational postmodernity, in its diaspora, as elsewhere, globally, Ireland's search for the past continues to be driven by the deficiency of the present. The façade of modernisation hides hollow foundations. The nostalgia of I Could Read the Sky is conjured by a lack in 'global' Ireland's present; it is the ghostly, 'unforgettable forgotten' of both the premodern and postmodern ideal.

In representing a 'past-present' obscured by a succession of fantasies, this novel suggests the importance today of what Ashis Nandy calls 'critical traditionalism'. ${ }^{83} \mathrm{~A}$ different kind of spatial and temporal connectedness is proposed, acknowledging the compulsion, in particular contexts, to revisit the past, and also its potential for the future. To include the past in the way advocated by Berger requires strategic narratives of history and identity. Drawing on Paul Ricoeur, Richard Kearney suggests just such a process in advocating contemporary, global Ireland's 'remythologisation'. This would act as a necessary counter to the anti-nationalist 'demythologisation' undertaken so thoroughly during the 1970s and 1980s. 'Myth,' Kearney argues, 'is a two way street', and in particular situations can: 
lead to the projection of genuine utopias ... Without mythology, our hopes and memories are homeless ... We must never cease to keep our mythological images in dialogue with history; because once we do we fossilise. That is why we will go on telling stories, inventing and re-inventing myths, until we have brought history home to itself. ${ }^{84}$

In certain contexts, then, 'the "past-present",' as Homi Bhabha puts it, 'becomes part of the necessity, not the nostalgia, of living. ${ }^{\prime 85}$ Having worked through Moore's anti-nostalgic anti-nationalism and emerged into the global economy on the other side, O'Grady and Pyke's book might best be described as 'post-nostalgic'.

\section{REFERENCES}

Timothy Dow Adams, Light Writing and Life Writing: Photography in Autobiography (Chapel Hill \& London: University of North Carolina Press, 2000).

Aidan Arrowsmith, 'Inside/Out: Literature, Cultural Identity and Irish Migration to England', in Comparing Postcolonial Literatures: Dislocations, edited by A. Bery \& P. Murray, (London: Macmillan, 2000), pp.59-69.

Benedict Anderson, 'Exodus', Critical Inquiry 20 (Winter 1994), pp.314-27.

Jean Baudrillard, Simulations, translated by P. Foss, P. Patton \& P. Beitchman, (New York: Semiotext(e), 1983).

Roland Barthes, Camera Lucida: Reflections on Photography, translated by R. Howard, (London: Vintage, 1993). 
Walter Benjamin, 'Theses on the Philosophy of History', Illuminations, translated by Harry Zohn, (London: Fontana, 1992), pp.245-55.

John Berger, About Looking (New York: Pantheon, 1980).

Homi K. Bhabha, The Location of Culture, (London: Routledge, 1994).

Eavan Boland, Object Lessons: The Life of the Woman and the Poet in our Time (London: Vintage, 1996).

Terence Brown, Ireland: A Social and Cultural History 1922-85(London: Fontana, 1985).

Pavel Büchler, Ghost Stories: Stray Thoughts on Photography and Film (London: Proboscis, 1999).

David Cairns and Shaun Richards, Writing Ireland: Colonialism, Nationalism and Culture (Manchester:

Manchester University Press, 1988).

Dympna Callaghan, 'An Interview with Seamus Deane', Social Text 38 (1994), pp.39-50.

Joe Cleary, 'Towards a Materialist-Formalist History of Twentieth-Century Irish Literature', Boundary 2, 31:1 (2004), pp.207-41.

Daniel Corkery, Synge and Anglo-Irish Literature, (Cork: Cork University Press, 1931).

Michael Cronin, 'Speed Limits: Ireland, Globalisation and the War Against Time', in Kirby et al(eds), Reinventing Ireland, pp.54-66.

Seamus Deane, 'Introduction' to Terry Eagleton, Fredric Jameson and Edward Said, Nationalism, Colonialism and Literature, (Minneapolis: University of Minnesota Press, 1990), pp.3-19.

Seamus Deane, Reading in the Dark (London: Jonathan Cape, 1996).

Don DeLillo, Underworld (New York: Simon \& Schuster, 1997).

Jacques Derrida, 'The Deaths of Roland Barthes', in Philosophy and Non-Philosophy Since Merleau-Ponty, edited by Hugh J. Silverman, translated by Pascale-Anne Brault and Michael Naas, (Evanston: Northwestern University Press, 1997), pp.259-343.

Eamon de Valera, 'The Undeserted Village Ireland', in The Field Day Anthology of Irish Writing: Vol.III, edited by Seamus Deane (Derry: Field Day Publications, 1991), pp.747-49.

Sarah Jane Edge, 'Photographic History and the Visual Appearance of an Irish Nationalist Discourse 18401870', Victorian Literature and Culture, 32:1 (2004), pp.17-39. 
David Fitzpatrick, Politics and Irish Life, 1913-21: Provincial Experience of War and Revolution (Dublin: Gill \& Macmillan, 1977).

Eóin Flannery, 'Reading in the Light of Reading in the Dark, Irish Studies Review 11:1 (2003), pp.71-80.

Roy Foster, 'Introduction', Paddy and Mr. Punch: Connections in Irish and English History (Harmondsworth: Penguin, 1995), pp.xi-xvii.

Roy Foster, 'We Are All Revisionists Now', The Irish Review No.1 (1986), pp.1-5.

Luke Gibbons, Transformations in Irish Culture (Cork: Cork University Press, 1996).

Luke Gibbons, 'The Global Cure? History, Therapy and the Celtic Tiger', in Kirby et al(eds), Reinventing Ireland, pp.89-106.

Colin Graham, Deconstructing Ireland: Identity, Theory, Culture (Edinburgh: Edinburgh University Press, 2001).

Seamus Heaney, Death of a Naturalist (London: Faber \& Faber, 1966).

Siobhán Holland, 'Decolleenising Women's Voices: Gender and National Fiction in Brian Moore's The Mangan Inheritance', in Space \& Place: The Geographies of Literature, edited by Glenda Norquay \& Gerry Smyth, (Liverpool: Liverpool John Moores University Press, 1997), pp.167-79.

Jefferson Hunter, Image and Word: The Interaction of Twentieth-Century Photographs and Texts (Cambridge, Mass.: Harvard University Press, 1987).

Clare Hutton, 'Joyce and the Institutions of Revivalism', Irish University Review 33.1 (2003), pp.117-32.

Fredric Jameson, Postmodernism or, The Cultural Logic of Late Capitalism (New York \& London: Verso, 1991).

Franz Kafka, America (1927), trans W. \& E. Muir; in Franz Kafka, The Trial, America, etc. (London: Secker \& Warburg, 1976), pp.131-272.

Richard Kearney, 'Myth and Motherland', in Ireland's Field Day, Field Day Theatre Company (London: Hutchinson, 1985), pp.61-80.

Declan Kiberd, 'Inventing Irelands', The Crane Bag, Vol. 8, No. 1, (1984), pp.11-23.

Declan Kiberd, Inventing Ireland: The Literature of the Modern Nation (London: Jonathan Cape, 1995). 
Nicola King, Memory, Narrative, Identity: Remembering the Self, (Edinburgh: Edinburgh University Press, 2000).

Peadar Kirby, Poverty Amid Plenty: World and Irish Development Reconsidered (Dublin: Trócaire/Gill \& Macmillan, 1997).

Peadar Kirby, Luke Gibbons and Michael Cronin (eds), Reinventing Ireland: Culture, Society and the Global Economy, (London: Pluto, 2002).

Peadar Kirby, Luke Gibbons and Michael Cronin, 'Introduction: The Reinvention of Ireland: A Critical Perspective', in Kirby et al (eds), Reinventing Ireland, pp.1-18.

Peader Kirby, 'Contested Pedigrees of the Celtic Tiger', in Kirby et al (eds), Reinventing Ireland, pp.21-37.

Celia Lury, Prosthetic Culture: Photography, Memory and Identity (London: Routledge, 1998).

Jean-François Lyotard, Heidegger and "the jews", translated by A. Michel \& M.S. Roberts, (Minneapolis: University of Minnesota Press, 1990).

Colum McCann, Songdogs (London: Phoenix House, 1995).

Vic Merriman, 'Decolonisation Postponed: The Theatre of Tiger Trash', Irish University Review 29:2 (Autumn/Winter 1999), pp.305-17.

Brian Moore, The Mangan Inheritance (1979) (London: Flamingo, 1995).

Chris Morash, '"Something's Missing": Theatre and the Republic of Ireland Act', in Writing in the Irish Republic: Literature, Culture and Politics 1949-1999, edited by Ray Ryan, (London: Routledge, 2000), pp.64-81.

Ashis Nandy, 'Cultural Frames for Social Transformation: A Credo', Alternatives, Vol.XII, No.1, (1987), pp.113-23.

Timothy O'Grady and Steve Pyke, I Could Read the Sky (London: Harvill Press, 1997).

Michel Peillon, 'Culture and State in Ireland's New Economy', in Kirby et al(eds), Reinventing Ireland, pp.3853.

Linda Haverty Rugg, Picturing Ourse/ves: Photography \& Autobiography (Chicago \& London: University of Chicago Press, 1997). 
Liam Ryan, 'Irish Emigration to Britain Since World War II', in Migrations: The Irish at Home and Abroad, edited by Richard Kearney, (Dublin: Wolfhound Press, 1990), pp.

Susan Sontag, On Photography (Harmondsworth: Penguin, 2002).

John Tagg, The Burden of Representation: Essays on Photography and History (London: Macmillan, 1988).

I would like to thank my colleagues in the English department at Staffordshire University for their very helpful comments on early drafts of this article.

1 John Dalberg-Acton, Essays in the Liberal Interpretation of History, (ed.) W.H. McNeill (Chicago; 1967); quoted by Benedict Anderson, 'Exodus', Critical Inquiry 20 (Winter 1994), p.315.

2 See Roy Foster, 'Introduction', Paddy and Mr.Punch: Connections in Irish and English History (Harmondsworth: Penguin, 1995), p.xiii, where he points out the Irish emigrant tendency to keep 'the memory of the homeland ... in aspic'; and also Foster's, 'We Are All Revisionists Now', The Irish Review No.1 (1986), p.3. Here that tendency is presented as a 'dangerous nostalgia' which is equated with support for the IRA. This, for Foster, is typically heard amongst the Irish in communities such as, 'Camden Town - where one is told that the only work of "real history" to have come out of Ireland is Gerry Adams's Falls Memories, and where any discussion of the (largely unknown and unwritten) history of 1916-22 will be deflected into sentimental reminiscences of "the songs we sang in my auntie's front room."' It is significant, of course, that the latter position emerges from the context of mid-1980s Britain and is therefore pressurised by the greater presence of Republican terrorism.

3 Declan Kiberd, Inventing Ireland: The Literature of the Modern Nation (London: Jonathan Cape, 1995), p.99.

${ }^{4}$ Hutton highlights the Southwark Irish Literary Club in London, founded in 1883 and including many prominent Irish emigrant cultural figures, as being 'particularly significant for the institutional genesis of the Irish cultural revival ... help[ing] to form the nucleus of London's Irish Literary Society.' Clare Hutton, 'Joyce and the Institutions of Revivalism', Irish University Review 33.1 (2003), p.120.

5 De Valera was born in New York in 1882, of a Spanish father and Irish mother. The Gaelic League was founded in 1893.

6 Terence Brown, Ireland: A Social and Cultural History 1922-85 (London: Fontana, 1985), p.154.

7 This phraseology is from David Fitzpatrick, Politics and Irish Life, 1913-21: Provincial Experience of War and Revolution (Dublin: Gill \& Macmillan, 1977), p.232: '[if] revolutions are what happen to wheels, then Ireland underwent a revolution between 1916 and 1922 ... social and political institutions were turned upside down, only to revert to full circle upon the establishment of the Irish Free State.'

${ }^{8}$ Eamon de Valera, 'The Undeserted Village Ireland', in The Field Day Anthology of Irish Writing: Vol.III, edited by Seamus Deane (Derry: Field Day Publications, 1991), pp.747-48.

${ }^{9}$ Chris Morash, "'Something's Missing": Theatre and the Republic of Ireland Act', in Writing in the Irish Republic: Literature, Culture and Politics 1949-1999, edited by Ray Ryan, (London: Routledge, 2000), p.71.

10 Joe Cleary, 'Towards a Materialist-Formalist History of Twentieth-Century Irish Literature', boundary 2, $31: 1$ (2004), p.230.

11 On the debates around the term 'postnationalism' as it relates to Ireland, see Colin Graham, Deconstructing Ireland: Identity, Theory, Culture (Edinburgh: Edinburgh University Press, 2001), especially pp.81-101. 
12 Fredric Jameson, Postmodernism or, The Cultural Logic of Late Capitalism (New York \& London: Verso, 1991), p.xix.

13 Michel Peillon, 'Culture and State in Ireland's New Economy', in Reinventing Ireland: Culture, Society and the Global Economy, edited by Peadar Kirby, Luke Gibbons and Michael Cronin, (London: Pluto, 2002), p.38.

14 Michael Cronin, 'Speed Limits: Ireland, Globalisation and the War Against Time', in Reinventing Ireland, p.56.

15 Kiberd, Inventing Ireland, p.565.

16 Luke Gibbons, Transformations in Irish Culture (Cork: Cork University Press, 1996), p.3.

17 See Peadar Kirby, Poverty Amid Plenty: World and Irish Development Reconsidered (Dublin: Trócaire/Gill \& Macmillan, 1997), pp.132-33, p.167.

18 Peader Kirby, 'Contested Pedigrees of the Celtic Tiger', in Reinventing Ireland, p.30.

19 Cronin, 'Speed Limits', p.61. The idealisation of poverty itself, embodied in the figure of the peasant, has a long history in Irish nationalism. In J.M. Synge's The Aran Islands (1907), for example, as in Robert Flaherty's film Man of Aran (1934), the hardship of life on these western isles is equated with authenticity and beauty, the bourgeois modernity embodied by Britain being the enemy of the ideal.

20 Kiberd, Inventing Ireland, p.24.

21 See Gibbons, Transformations, p.6.

22 Kiberd, Inventing Ireland, p.24.

23 See Cronin, 'Speed Limits', p.56. As Liam Ryan points out, Ireland retained an emigration rate of nineteenth-century intensity: 'In Ireland alone, in 1988, probably uniquely among the nations of the earth, did the number leaving the state ... come close to the annual number being born.' Liam Ryan, 'Irish Emigration to Britain Since World War II', in Richard Kearney (ed.), Migrations: The Irish at Home and Abroad (Dublin: Wolfhound Press, 1990), p.45.

24 Jean Baudrillard, Simulations, translated by P. Foss, P. Patton \& P. Beitchman, (New York: Semiotext(e), 1983), pp.12-13.

25 Jameson, Postmodernism, pp.17-18, p.25. Jameson distinguishes pastiche from parody: 'Pastiche is, like parody, the imitation of a peculiar or unique, idiosyncratic style, the wearing of a linguistic mask, speech in a dead language. But it is a neutral practice of such mimicry, without any of parody's ulterior motives, amputated of the satiric impulse, devoid of laughter and of any conviction that alongside the abnormal tongue you have momentarily borrowed, some healthy linguistic normality still exists.' (p.17).

${ }^{26}$ See Jeff Cottenden's design on the cover of Seamus Deane, Reading in the Dark (London: Jonathan Cape, 1996).

27 John Tagg, The Burden of Representation: Essays on Photography and History (London: Macmillan, 1988), p.65.

${ }^{28}$ Seamus Deane, 'Introduction' to Terry Eagleton, Fredric Jameson and Edward Said, Nationalism, Colonialism and Literature, (Minneapolis: University of Minnesota Press, 1990), p.8.

29 Dympna Callaghan, 'An Interview with Seamus Deane', Social Text 38 (1994), p.40.

30 Susan Sontag, On Photography (Harmondsworth: Penguin, 2002), p.15.

31 Examples of Hinde's images can be seen in Gibbons, Transformations, pp.36-43.

32 Gibbons, Transformations, p.40.

33 Daniel Corkery, Synge and Anglo-Irish Literature, (Cork: Cork University Press, 1931), p.19.

34 Seamus Heaney, 'Ancestral Photograph', Death of a Naturalist (London: Faber \& Faber, 1966), p.26. For a discussion of the influence of photography on Heaney's work, especially the 'Bog Poems' of the 1960s and 70s, see Jefferson Hunter, Image and Word: The Interaction of Twentieth-Century Photographs and Texts (Cambridge, Mass.: Harvard University Press, 1987), pp.183-95.

${ }^{35}$ See Hunter, Image and Word, pp.34-5.

36 Roland Barthes, Camera Lucida: Reflections on Photography, translated by R. Howard, (London: Vintage, 1993), pp.80-81.

37 Linda Haverty Rugg, Picturing Ourse/ves: Photography \& Autobiography (Chicago \& London: University of Chicago Press, 1997), p.11. 
38 For a survey of literary texts describing or containing photographs, see Timothy Dow Adams, Light Writing and Life Writing: Photography in Autobiography (Chapel Hill \& London: University of North Carolina Press, 2000), p. xvi, p.1.

39 Don DeLillo, Underworld (New York: Simon \& Schuster, 1997), pp.175-7. See also, for example, Paul Auster's The Invention of Solitude (1988), and Oracle Night (2004). For a reading of The Invention of Solitude as photo-text, see Adams, Light Writing and Life Writing, pp.25-39.

40 Jean-François Lyotard, Heidegger and "the jews", translated by A. Michel \& M.S. Roberts, (Minneapolis: University of Minnesota Press, 1990), p.26.

41 Hunter, Image and Word, pp.1-2.

42 Sontag, On Photography, p.16, p.24. Timothy Dow Adams traces the debate over photography's referentiality back to seventeenth-century painters, as well as figures such as John Ruskin and Joel Snyder. See Adams, Light Writing and Life Writing, pp.3-5.

43 Brian Moore, The Mangan Inheritance (1979) (London: Flamingo, 1995), p.8. Subsequent page references will appear in parentheses in the text.

44 Oliver Wendell Holmes, 'Sun-Painting and Sun Sculpture, with a Stereoscopic Trip across the Atlantic', Atlantic Monthly 8 (July 1861). Quoted by Adams, Light Writing and Life Writing, p.3.

45 Barthes, Camera Lucida, pp.26-7.

46 Nicola King, Memory, Narrative, Identity: Remembering the Self, (Edinburgh: Edinburgh University Press, 2000), p.178.

47 Barthes, Camera Lucida, p.12. See Celia Lury, Prosthetic Culture: Photography, Memory and Identity (London: Routledge, 1998), especially pp.76-80.

48 Eavan Boland, Object Lessons: The Life of the Woman and the Poet in our Time (London: Vintage, 1996), pp.134-6. Boland's critique has itself been convincingly attacked for retaining essentialist and nationalist notions of authenticity. See Siobhán Holland, 'Decolleenising Women's Voices: Gender and National Fiction in Brian Moore's The Mangan Inheritance', in G. Norquay \& G. Smyth (eds), Space \& Place: The Geographies of Literature (Liverpool: Liverpool John Moores University Press, 1997), pp.167-79.

49 Jamie's identification with the image of James Clarence Mangan recalls the links, discussed by Sarah Jane Edge, between photography and the growth of Irish nationalism during the nineteenth century. See Sarah Jane Edge, 'Photographic History and the Visual Appearance of an Irish Nationalist Discourse 1840-1870', Victorian Literature and Culture, 32:1 (2004), pp.17-39. Edge argues that photographs of Irish nationalist figures produced by the British state influenced the production 'of a shared identity of Irishness. While the photographs of the nationalist leaders promoted rather an exclusive discourse of middle-class, male heroism and individualism, the state-produced photographs facilitated the construction of a discourse of sameness that came to signify the nationalist (Irish) criminal/revolutionary. Somewhat ironically, in the following years, it was this very discourse on the essential sameness or uniqueness of being Irish that was to become the rationale for the much broader and widespread movement of cultural nationalism in Ireland that came to define a shared Irish cultural identity' (p.37). Mangan would have made an exemplary subject for such images but unfortunately his photograph was, as far as we know, never taken.

50 On these aspects of Irish migrant writing, see Aidan Arrowsmith, 'Inside/Out: Literature, Cultural Identity and Irish Migration to England', in Comparing Postcolonial Literatures: Dislocations, edited by A. Bery \& P. Murray, (London: Macmillan, 2000), pp.59-69.

51 Hunter, Image and Word, pp.1-2.

52 All photographs by Steve Pyke and copyright (C) Steve Pyke, 1997. Reproduced here by kind permission of the artist.

53 Timothy O'Grady and Steve Pyke, I Could Read the Sky (London: Harvill Press, 1997), pp.15-6. Subsequent page references will appear in parentheses in the text.

54 Seamus Deane, 'Different Strokes: Politically Charged Fiction from Northern Ireland; A Biography of an Eccentric British Expatriate', an interview with Seamus Deane by Nicholas Patterson, Boston Phoenix, 411 June 1998. Quoted by Eóin Flannery, 'Reading in the Light of Reading in the Dark, Irish Studies Review 11:1 (2003), p.73.

55 Declan Kiberd, 'Inventing Irelands', The Crane Bag, Vol. 8, No. 1, (1984), pp.11-13. 
56 As Gibbons points out in relation to Hinde's images, the 'prodigal colour and total artifice of [Hinde's] narratives suggest that there is no real prospect of returning home.' Gibbons, Transformations, p.40.

57 Sontag, On Photography, p.15.

58 Pavel Büchler, Ghost Stories: Stray Thoughts on Photography and Film (London: Proboscis, 1999), p.83.

59 Cleary, 'Towards a Materialist-Formalist History', p.233.

60 Cleary, 'Towards a Materialist-Formalist History', p.234.

61 Peadar Kirby, Luke Gibbons and Michael Cronin, 'Introduction: The Reinvention of Ireland: A Critical Perspective', in Reinventing Ireland, p.7.

62 Brown, Ireland, p.264.

63 Seamus Deane, quoted by David Cairns and Shaun Richards, Writing Ireland: Colonialism, Nationalism and Culture (Manchester: Manchester University Press, 1988), p.142. Original source unavailable.

${ }^{64}$ Luke Gibbons, 'The Global Cure? History, Therapy and the Celtic Tiger', in Reinventing Ireland, p.100.

65 Ireland Industrial Development Authority advertising campaign, reproduced in Gibbons, Transformations, p.87. Other contemporaneous slogans, as Gibbons shows, included: 'Missing the Industrial Revolution was the best thing that ever happened to Ireland'; and 'In the heart of the Irish countryside, the minds that attract U.S. business'. All were finished with the strapline: 'We're the Young Europeans'.

66 Gibbons, Transformations, p.86.

67 Kirby, et al, 'Introduction', p.10. Interestingly, Caffreys is at the time of writing, about to be rebranded once again. The name had been purchased from Bass by Interbrew PLC, who then sold it to American giant Coors. Their current plans for the brand include a re-launch as a non-Irish, non-ale in a bid to enter the British Premium lager market. Celtic Tiger Irishness, even in sanitised form, appears no longer to be a saleable commodity.

68 See Vic Merriman, 'Decolonisation Postponed: The Theatre of Tiger Trash', Irish University Review 29:2 (Autumn/Winter 1999), pp.305-17.

69 Kirby, 'Contested Pedigrees', in Reinventing Ireland, p.23.

70 See J.M. Synge, The Aran Islands (1907), in Collected Plays and Poems and The Aran Islands (London: Everyman, 1997), pp.251-382. See also Irish-American filmmaker Robert Flaherty's 1934 movie Man of Aran.

71 Franz Kafka, America (1927), trans W. \& E. Muir; in Franz Kafka, The Trial, America, etc. (London: Secker \& Warburg, 1976), p.180.

72 Barthes, Camera Lucida, pp.68-9.

73 Colum McCann, Songdogs (London: Phoenix House, 1995), p.138, p.141.

${ }^{74}$ Barthes, Camera Lucida, p.64, p.106.

75 Images such as these call to mind one of the very first photo-texts, entitled The Door in the Wall(1911), in which H.G. Wells's short stories are married with photographs by Alvin Langdon Coburn, and Seamus Heaney's 1969 volume of poetry Door into the Dark, which often concerns the search for roots. For a history of the photo-text, see Hunter, Image and Word.

76 Peter Woods, 'Exile', used as epigraph to I Could Read the Sky.

77 John Berger, 'Preface' to O'Grady and Pyke, (unpaginated preface).

78 Barthes, Camera Lucida, p.55.

79 John Berger, About Looking (New York: Pantheon, 1980), p.57. Quoted in Hunter, Image and Word, p.65.

80 Walter Benjamin, 'Theses on the Philosophy of History', Illuminations, translated by Harry Zohn, (London: Fontana, 1992), pp.252-3.

$\mathbf{8 1}$ King, Memory, Narrative, Identity, pp.178-9.

82 Jacques Derrida, 'The Deaths of Roland Barthes', in Philosophy and Non-Philosophy Since Merleau-Ponty, edited by Hugh J. Silverman, translated by Pascale-Anne Brault and Michael Naas, (Evanston: Northwestern University Press, 1997), p.264.

83 Ashis Nandy, 'Cultural Frames for Social Transformation: A Credo', Alternatives, Vol.XII, No.1, Jan.1987, p.114. For Nandy, 'critical traditionalism' is generated as a response to globalisation and cultural imperialism, being 'a plea for minimum cultural plurality in an increasingly uniformised world.'

84 Richard Kearney, 'Myth and Motherland', in Ireland's Field Day, Field Day Theatre Company (London: Hutchinson, 1985), p.80. 
85 Homi K. Bhabha, The Location of Culture, (London: Routledge, 1994), p.7. 